\title{
Honorary Intermediaries?
}

The Chinese People's Political Consultative Conferences in Theory and Practice

Rebekka Åsnes Sagild and Anna Lisa Ahlers

\section{OpenEdition}

\section{Journals}

Electronic version

URL: http://journals.openedition.org/chinaperspectives/9016

DOI: 10.4000/chinaperspectives.9016

ISSN: 1996-4617

\section{Publisher}

Centre d'étude français sur la Chine contemporaine

Printed version

Date of publication: 8 June 2019

Number of pages: 9-16

ISSN: 2070-3449

\section{Electronic reference}

Rebekka Åsnes Sagild and Anna Lisa Ahlers, « Honorary Intermediaries? », China Perspectives [Online], 2019-2 | 2019, Online since 10 June 2020, connection on 23 December 2020. URL : http://

journals.openedition.org/chinaperspectives/9016; DOI : https://doi.org/10.4000/chinaperspectives. 9016 


\title{
Honorary Intermediaries?
}

\author{
The Chinese People's Political Consultative Conferences in Theory and Practice
}

\author{
REBEKKA Å. SAGILD AND ANNA L. AHLERS
}

\begin{abstract}
The Chinese People's Political Consultative Conference (CPPCC) system is a curious institution: often ridiculed as a decorative "flower vase" for the one-Party regime, or, at best, a networking club meant to appease elite groups, it does not attract much scholarly attention. The Communist Party leadership, however, clings adamantly to what it says is a "broadly representative" intermediary body helping with policy reform and United Front work. In this article, we investigate the validity of this original logic with the help of fresh empirical data. We look at the CPPCC's institutional history, principles of member selection, delegates' self-conceptualisation, and their modes of operation. Intermediation, it appears, has always been a blurry task for CPPCC members, resulting in a wide array of behavioural choices - from parroting of the Party line to attempts at proactive agenda setting. After more than two decades of relative openness to innovative bottom-up policy proposals, new rules of unified conduct now again stifle the consultative potential of the CPPCCs - but there seems to be some room for intermediary agency left, especially at the local level.
\end{abstract}

KEYWORDS: CPPCC, Chinese political system, United Front, intermediary bodies, representation, elite politics, consultation.

\section{Introduction}

W hile neither a body of state power nor a policy-making organ the Chinese People's Political Consultative Conferences (CPPCC) hold a curious position in the Chinese political system. These conferences exist across almost the entire Chinese political hierarchy and are supposed to be Party-external consultative fora. (1) The CPPCC's main functions officially comprise forging the Party-state's corporatist relationship with mass organisations, intermediation between the state and societal groups, and all sorts of other general "Patriotic United Front" work (Groot 2012: 30; Wang and Groot 2018). This implies that the CPPCC is meant to include people from the eight minor parties, minorities and religious leaders, and different segments of the general Chinese population, including overseas Chinese ; or in the Chinese Communist Party's (CCP) own words, in short: "people from all walks of life." (2) Estimations of the number of representatives range upwards of 700,000, including "friendship associations" (zhengxie zhi youshe 政协之友社), which are set up in major cities and host up to several thousand former members of the CPPCC.

The CPPCC system is officially supposed to serve a "bridging" function, enabling communication between the people and the government. ${ }^{(3)} \mathrm{Mem}$ bers of the conferences are tasked with proposing policies, conducting democratic supervision, and participating in the deliberation of state affairs. In other words, the CPPCC is supposed to facilitate the articulation of plural voices in the political process, in support of the other, all heavily CCP-dominated institutions, for the ultimate sake of policy reform. At the same time, the consultative conferences are to "follow the leadership of the CCP," and their actual membership composition, especially the disproportional share of rich business people and high-status persons, seems to contradict the official claim of "broad-based representation." These characteristics have earned the CPPCC the tag "flower vase" (huaping 花瓶) in colloquial usage, pointing to its obviously very limited meaning and mere window-dressing function. ${ }^{\left({ }^{4}\right)}$ Nonetheless, in scholarly literature, the CPPCC has sometimes been characterised as one of the platforms the Party-state uses to safeguard support for its policy agenda and rule: through institutionalised consultation with a limited selection of social groups, under a quasi-democratic pretence, in the view of some of these observers, the CPPCC contributes to elite cooptation (Dickson 2008; Chen 2015) and potentially to what is referred to as authoritarian regime resilience in China (Yan 2011; Sun, Zhu, and Wu 2014). Yet, overall, systematic research on the CPPCC is sparse; besides Yan Xiaojun's (2011) pioneering study of a local CPPCC in Hebei Province, the few existing studies of the CPPCC usually focus on quite specific aspects, such as biographies of or specific groups among the members (entrepreneurs, celebrities), case studies of a particular locality, or statistics of documented outputs (proposals), etc. (see e.g. Li, Meng, and Zhang 2006; Chen, Lu, and He 2008; Lu 2014; Chen 2015; Jeffreys 2016).

This article, in line with the research interest of this special issue, will explore if and how the CPPCC functions as an intermediary body in Chinese politics. The institution's official mandate is that of providing a "bridge" between society and the Party-state, enabling multi-party cooperation, and eventually offering policy advice. Intriguingly, however, neither the criteria for selection of members of the CPPCC, in other words, their qualifications, nor the ways in which they are expected to exert their tasks as "intermediaries" and "consultants" were ever defined in specific and transparent terms.

1. For reasons of readability, CPPCC here denotes the overall institution in the Chinese political system that we find at the national and provincial level, in autonomous regions, and municipalities directly under the Central Government, cities at prefectural level, autonomous counties and cities at county-level, as well as in districts under the jurisdiction of cities. Where it is of significant importance for our argument, we have pointed out whether we are referring to the central level CPPCC or a particular subnational committee.

2. 各界 gejie is the term most often used in this case, usually translated into "people from all walks of life" in official translations of CPPCC documents.

3. The formulation unanimously used by our informants across all levels is: "老百姓跟政府的一个 沟通桥梁" (laobaixing gen zhengfu de yi ge goutong qiaoliang); Interviews, August 2017, April and July 2018 in Zhejiang Province.

4. Another popular saying goes "人大举举手, 政协拍拍手" (Renda jujushou, zhengxie paipaishou, NPC members raise their hands, CPPCC members clap their hands). 
Based on existing primary and secondary sources on the CPPCC and our own empirical data, we therefore first briefly reconstruct the evolution of the CPPCC and its function in the Chinese political system. We then trace the discernible logic behind the selection of CPPCC delegates, check how this is reflected in the real development of the CPPCC's membership composition over time, and identify the guiding principles and forms of eventual CPPCC work. In particular, we offer new empirical insights as to if and how CPPCC members themselves see and interpret their role as intermediaries today.

The empirical basis for this article emerges from work conducted for a research project on forms of political inclusion in authoritarian regimes and an individual study of the institutional history of the CPPCC hosted and financed by the University of Oslo. It builds upon preliminary findings from two rounds of ethnographic field research conducted by the lead author in 2017 and 2018. The search for informants was conducted on the basis of personal contacts and the snow-balling method and has so far resulted in 15 semi-structured in-depth interviews with members of the CPPCC at the national level, as well as of sub-provincial city and county-level city CPPCC committees in Zhejiang Province. We further draw on related reporting in Chinese media from 1949 until today, information gathered from CPPCC websites and Party and government publications, including biographical information and obituaries, and a review of scholarly work on the CPPCC.

Altogether, we contend that the CPPCC cannot be regarded as a classical intermediary body as it was conceptualised in the introduction to this special issue, that is, as a "transmission belt" or an arbitrator between the Party-state and societal groups, aggregating and representing particular interests. Despite significant interpretational and practical shifts over time, the CPPCC system does not follow a clear logic of representation or even indirect interest mediation. Apparent selection principles indicate that social status is equated with political importance and consultative capability. Delegates themselves speak of their mandate as an honorary obligation, but as we will describe, their actual tasks remain rather blurry. Traditionally, this has resulted in a wide array of behavioural choices for CPPCC members - from parroting of the Party line to attempts at proactive policy agenda setting. Yet, after roughly three decades of relative openness to bottom-up policy input, in today's political context intermediation in the CPPCC has been diminished again to instead consist of a) a top-down mission of propagating the "Party line" as broadly as possible, and b) loose consultative practices in support of the CCP's pre-existing policy regime. This does not mean that there is no more opportunity for innovative intermediary agency and proactive consultation; however, it appears to be a rather rare and increasingly limited feature with few tangible results. Unlike the findings of studies of People's Congresses and their delegates in contemporary China (Manion 2015; Truex 2016), CPPCC members' self-description and interpretation of their role is predominantly conservative and passive, although with a few individual and especially local exceptions.

\section{Evolution of the CPPCC as a bridge between the Party-state and society}

Despite having been at the brink of abolishment a few times in the history of the People's Republic of China (PRC), the CPPCC seems alive and kicking today. Xi Jinping recently called for its invigoration and described it as the manifestation of a "new type of party system" (xinxing zhengdang zhidu 新 型政党制度). ${ }^{(5)}$ According to a recent op-ed in People's Daily, the CPPCC more than ever embodies "multi-party cooperation and political consultation under the leadership of the CCP." Reiterating that the CPPCC system helps to pool ideas from "people from all walks of life," People's Daily describes it as the solution to "outdated" Western practices of democracy. ${ }^{(6)}$ Yet, despite this expressed importance, the CPPCC has always been situated outside the formal political structure. It is the first of nine bureaus under the United Front Work Department (UFWD), an agency tasked with managing relations with people outside the Party proper who are deemed important for assembling support, special skills, and knowledge in order to sustain the rule of the Communist Party. ${ }^{(7)}$

Who these people are, and how this translates into membership and mandates in the case of the CPPCC, has been subject to some quite remarkable interpretative and practical changes over time. Briefly tracing these shifts in a first approach to understanding the notions of intermediation at work in the CPPCC, we can roughly identify three different stages that more or less overlap with the common political historiography of the PRC. At all times, the CCP's quest for political stability and hegemony have been at the centre. The period from 1948-1949 and throughout the Mao era featured a form of "top-down" (inter)mediation where the focus was on consolidating CCP rule and using the CPPCC as an institution to spread ideas downwards, with little room for upward voice. The second stage, following the complete political chaos of the Cultural Revolution, entailed the reinstatement of the CPPCC in 1978 and the reinvigoration of the minority parties. This was a period of political consolidation, but it also featured attempts by CPPCC members to exercise political influence and gain more traction for the idea of turning the CPPCC into a truly relevant body. Most importantly, this period saw the early inclusion of private entrepreneurs and calls for intensified "reflection work" on social issues in the CPPCC. Finally, since around 2010, the third stage is marked by a return to ideological correctness and more authoritarian oversight, culminating in recent comments by the Party leadership that again limit the work of the CPPCC in line with the general re-centralisation that is now observable all over the Chinese political system.

\section{9-1978: Managing Party-intelligentsia relations}

Towards the end of the Chinese civil war, in January 1948, the CCP began to focus on using minority political parties and other groups to consolidate support in order to overthrow the Kuomintang (KMT), and preparations for the first CPPCC began. In the initial phase, CCP members consulted with trusted left-wing party leaders to decide on topics of discussion for the first CPPCC, which were consequently relayed to minority party leaders in other areas (Groot 2004: 50). In particular, they were handed copies of CCP policy documents and works by Mao, Lenin, and Marx with the goal of converting non-Party forces to follow the CCP line (ibid.: 51). In May 1948, the CCP sent out the "May $1^{\text {st }}$ Call" (wuyi kouhao 五一口号), urging, among other things, "all democratic parties, various people's organisations, and various social elites to quickly convene a political consultative meeting to discuss and realise the convening of the people's congresses and the establishment

5. Xi Jinping at the first plenary session of the $13^{\text {th }}$ CPPCC (2018): "What is a 'new type of party system'?," China.org.cn, 23 March 2018, http://www.china.org.cn/china/2018-03/23/content_ 50741576.htm (accessed on 5 December 2018)

6. "Op-ed: China's new type of party system enlightens the world," People's Daily, 12 March 2018, http://en.people.cn/n3/2018/0312/c90000-9435991.html (accessed on 1 December 2018).

7. For a historical account of the United Front see Van Slyke (1967); for a more recent contribution see Groot (2004) 
of a democratic coalition government!" (8) Eventually, 38 non-CCP groups, in exchange for pledging their allegiance to the CCP, accepted the invitation to the first meeting in September 1949. At the meeting the CPPCC passed the Organic Law of the CPPCC, the Organic Law of the Central People's Government, and the Common Program, and endorsed the new national flag, the national anthem, and a new calendar (ibid.: 163). With the ensuing official founding of the People's Republic of China under the aegis of the CCP on 1 October 1949, the CPPCC had effectively concluded its role as an organ of state power. However, it was not dissolved but immediately transformed into a core institution of the CCP's United Front, while the National People's Congress (NPC) later assumed the role as the de facto parliament.

Especially in the early phase, the Party used CPPCC members as role models for promoting state campaigns and as a means to spread the CCP's influence and put pressure on potential opponents when needed (Van Slyke 1967: 215). Throughout the Mao era, intellectuals (zhishifenzi 知识分子) and other non-Party elites were particular targets of United Front efforts to cultivate support and unity. Intellectuals allegedly provided a functional link between the nascent state and society; they were considered important intermediaries as they could formulate their own demands, as well as those of the people (Bonnin and Chevrier 1991: 573). Being selected to join the CPPCC in turn seemed to offer an opportunity to voice opinions within given boundaries set by the Party. During Mao's "Hundred Flowers Campaign" in 1956, for instance, delegates sent to the CPPCC were promised a platform to speak freely under the condition that they accepted criticism in return (Groot 2004: 40). While many among the elite were initially sceptical, the CCP regime tried to ensure these actors' participation through building personal connections and trust and by helping them maintain their status and privilege (Eddy 2012). This construct lasted less than a year, however, until many protagonists fell victim to the Anti-Rightist purges in 1957. (9) The most crucial feature of intermediation in the CPPCC in this period was that even those who were officially declared non-Party representatives were practically indistinguishable from CCP members. In fact, opinions uttered had to correspond strictly with the Party line, and there was no room for the slightest diversion, or in other words, innovation. The underlying logic corresponds with early United Front ideology, i.e., selected members to the consultative conferences were supposed to be neither members of the CCP nor outright "opponents." This form of top-down mobilisation was not a serious attempt at including different groups and different views to solve problems, but rather had to do with Party leaders' ambition to mend ties with the intelligentsia and to keep it under control (Van Slyke 1967).

\section{8-2010s: Attempts at mediating social differentiation}

After being (functionally) shut down during the Cultural Revolution (19661976), the CPPCC was revived again in 1978, with Deng Xiaoping as the chairperson. That year, as the CCP abandoned class struggle in order to pursue economic modernisation at its third plenum in December, the Central Committee of the CCP also reported that the intellectuals' "situation was now under control." (10) The same period further saw the reinvigoration of the minor parties and offered some opportunities for an increased role for the CPPCC. At the fifth CPPCC (1978-1983), the member category of "specially invited personages" grew substantially. However, despite the suggestion that this indicated an intention of the CCP to "ease tension and solidify control" (Yu 2015: 443) in an increasingly diverse society, what we see is that even in this group at least 400 delegates (of total 993) were already members of the CCP, and at least 25 followed suit in the five years immediately afterwards. ${ }^{(11)}$ In fact, CCP members made up the bulk of all representatives until 1983, when a $40 \%$ cap on CCP members was introduced. (12) A major United Front objective at the time was to include more and younger intellectuals in the CPPCC, at the expense of peasants and workers (Groot 2004: 119). During the 1980s and after, formal recognition of new socio-economic groups and the prospect of them helping to steer the unfolding economic development in China was underlined in work reports. ${ }^{13)}$ However, perhaps the clearest example of actual intermediary activity in the CPPCC at the time also testified to the institution's overall weak formal status: in the mid-80s, members of the CPPCC became heavily involved in discussions about the construction of the Three Gorges Dam, collecting and promoting public opinions and expert advice. These, however, were largely negative, to the point of creating conflict between the CPPCC and the ministries overseeing the building of the dam (ibid:: 140). (14) Despite successfully generating public input and even pointing to resistance, in the end, the central government did not incorporate the CPPCC's feedback and did not budge from its original plans.

Yet, in the early 1990s, a new task was added to CPPCC delegates' work portfolio, meant to institutionalise a form of information ("opinion") collection, officially from among the "broad masses," which could then be transmitted quickly to CCP and governmental bodies (see also below). The most remarkable and rather sudden development, however, was that private entrepreneurs were formally invited to join the CPPCCS' new "economics circle" in 1993. Almost ten years prior to the introduction of then-President Jiang Zemin's "Three Represents" (sange daibiao 三个代表) in 2001-2002, (15) the consultative conferences were already welcoming wealthy businesspeople and promoting the entrepreneurial skills of representatives, fundamentally at odds with the CCP's traditional ideology. Previously excluded from Party and government offices, entrepreneurs sought CPPCC member-

8. Exclamation point in the original; see:“中共中央发布“五一'劳动节口号('五一口号')” (Zhonggong zhongyang fabu "wuyi" laodong jie kouhao ("wuyi kouhao")), The Central Committee of the Chinese Communist Party issues the May $1^{\text {st }}$ Labour Day call ("May $1^{\text {st }}$ call")), Xinhua, 1 May 1948, http://www.cppcc.gov.cn/2011/12/16/ARTI1513333598602528.shtml (accessed on 15 May 2018).

9. This includes the then head of the UFWD, Li Weihan 李维汉.

10. “中共中央组织部关于落实党的知识分子政策的几点意见” (Zhongguo zhongyang zuzhibu guanyu luoshi dang de zhishifenzi zhengce de ji dian yijian, Opinions of the CCP Central Committee Organisation Department on implementing the Party's policies towards intellectuals), CPC News, 3 January 1978, http://cpc.people.com.cn/GB/64184/64186/66706/4495781.html (accessed on 5 May 2018).

11. This is according to biographical data we compiled; available upon request.

12. “巩固和发展中华民族的大团结大统一一祝贺政协六届一次会议开幕(社论)" (Conggu he fazhan Zhonghua minzu de da tuanjie da tongyi - zhuhe zhengxie liu jie yici huiyi kaimu (shelun), Consolidating and developing the great unity of the Chinese nation - Congratulations on the opening of the first meeting for the six circles of the CPPCC (Editorial)), Renmin Ribao, 4 June 1983.

13. “胡子昂在六届全国政协常委会工作报告中指出一政协工作为经济建设服务大有可为” (Hu Zi'ang zai liu jie quanguo zhengxie changweihui gongzuo baogao zhong zhichu - zhengxie gongzuo wei jingji jianshe fuwu dayoukewei, Hu Zi'ang points out in the work report of the Standing Committee of the sixth CPPCC National Committee - The work of the CPPCC is very promising for economic construction), Renmin Ribao, 26 March 1985

14. "The Three Gorges Dam in China: Forced Resettlement, Suppression of Dissent and Labor Rights Concerns," Human Rights Watch, 1 February 1995, https://www.refworld.org/docid/3ae6a7d 310.html (accessed on 13 January 2019)

15. The concept of the Three Represents means that the CCP ought to represent the development trends of advanced productive forces, advanced culture, and the interests of the overwhelming majority of the Chinese people. "Advanced productive forces" in this formula was basically interpreted as the private economic sector, i.e., private entrepreneurs. This ideological reform is largely seen as symbolising the Party's final turn from an exclusive and revolutionary party to a catchall sort of people's party; see, for example, Holbig (2006). 
ship in great numbers, as it allowed them to cultivate ties with officials, and to obtain preferential treatment for their businesses - in short, it represented a response to state, market, and legal failures in China (Li, Meng, and Zhang 2006: 560-3). While policy proposals coming out of the economics groups were rarely implemented, (16) the conferences offered the opportunity to promote collective statements reflecting the entrepreneurs' demands vis-à-vis the government and to pursue individual interests (Yu 2015). ${ }^{(17)}$ Thus, despite obvious and rational attempts at strengthening the role of the CPPCC and increasing its influence on important national policy-making, the major change in the CPPCC system in this period was the introduction of new groups who were supposed to represent some sort of collective interest, but were instead usually intermediating their own individual demands.

\section{0s to the present: A return to top-down control}

Since the 2000s, the CPPCC appears to be one of the main vehicles by which the CCP is aiming at a better integration of the country's new elites in order to avoid any attempts at creating separate political organisations (Cabestan 2017). This corresponds well with the marked influx of rich entrepreneurs, media personalities, and technological entrepreneurs, especially at the central-level CPPCC. The $13^{\text {th }}$ (2018) National CPPCC, for instance, comprised 59 billionaires, including, among others, almost half of the CEOs of Hong Kong's large media companies and other tycoons. Perhaps as an attempt to counter the resulting elitist reputation of the CPPCC, three migrant workers were invited to join the national CPPCC in 2008 (Lin 2014: 145). It remains an open question, however, whether the CPPCC today is a "better" forum for co-opting economic elites than the Party itself or personal relations to decision-makers, and not just a rather empty shell - especially when looking at the CPPCC's internal organisation and delegates' actual activities, as we will do below. Furthermore, in a turnaround from the previous phase, the CCP is now once more exchanging the relatively open approach at intermediation of ideas for an adamantine top-down ideological control. In October 2018, the CCP's Central Committee published a new Opinion on the Conduct of the CPPCC, re-emphasising that the CPPCC ought to adhere to Xi Jinping's core status (hexin diwei 核心地位) in Chinese politics, to act as a political organisation (zhengzhi zuzhi 政治组织), and to take a clear stand when discussing political issues, in other words: to not oppose central policies. ${ }^{(18)}$ In addition, in recent statements calling for a revival of the United Front, the importance of political loyalty is always underlined. (19)

The result is that CPPCC representatives again overtly appear almost indistinguishable from CCP members. In fact, despite the emphasis on inclusion of minor party members, there have been numerous instances where it was discovered that CPPCC members who were officially representing one of the other eight parties were also members of the CCP. ${ }^{(20)}$ Adding to this, the recent introduction of the principle that "whoever recommends someone is responsible for this person" (shei tuijian, shei fuze 谁推荐, 谁负 责) (21) makes for an even more unitary bias in the CPPCC. This increasingly discourages non-conformity, and our observations confirm that the window for innovative proposals has been gradually shut again. This current atmosphere was aptly summarised when, in response to a question about the purpose of the CPPCC, a former national-level conference member quoted former CPPCC Chairperson Li Ruihuan in saying: "Helping out without adding inconvenience" (bangmang, bu tianluan 帮忙, 不添乱). The "helping out," she explained, carried a double meaning: to help the government avoid trouble, and to help by raising good proposals. (22)

Finally, through all the years, what stays constant beyond shifts in the notion of what intermediation in the CPPCC should look like, and which issues should or can be subject to discussion, is the fact that the CPPCC system embodies an approach that equates social status with political importance and capability. It therefore makes sense to scrutinise if and how this is reflected in member selection and delegates' actual work.

\section{Mobilised representation: Selection process and internal organisation}

Little is known about the necessary criteria for, and the process of, becoming a CPPCC member. Apparently, representatives are supposed to be able to intermediate between (collective) interests present among the people and the goals of the political regime by virtue of their high social status and personal qualities. Yet, as indicated earlier, this does not necessarily result in a membership composition that could reflect a cross section of the Chinese population (see Table 1).

According to the latest update of the CPPCC charter in 2018, delegates must furthermore "be representative of the sectors to which they belong, and have the necessary social influence and ability to participate in and deliberate state affairs." (23) What that means is again not specified and remains deliberately open to interpretation. Beyond that, there exists no transparent catalogue of the specific (political) merits a person must claim in order to be considered a capable CPPCC delegate and "bridge pier." It seems, however, that occupational background is increasingly crucial today. Article 38 of the new CPPCC charter stipulates that if a member changes jobs (s)he "should resign" (yingdang ciqu 应当辞去) from the CPPCC. Existing research

16. There are, however, a few exceptions, for instance the introduction of a property rights law that was first raised in the CPPCC in 2001, was then put on the NPC's agenda, and was finally passed in 2007 (Chen 2016: 327).

17. This tendency is also reported for other groups, of course. For the intellectual elite, for instance, CPPCC membership improves their chances of joining the Chinese Academy of Sciences (Cao 1999).

18. “中共中央办公厅印发关于加强新时代人民政协党的建设工作的若干意见” (Zhonggong zhongyang bangongting yinfa guanyu jiaqiang xin shidai renmin zhengxie dang de jianshe gongzuo de ruogan yijian, The General Office of the Central Committee of the Communist Party of China issues several opinions on strengthening Party-construction in the Chinese People's Political Consultative Conference in the new era), Xinhua, 14 October 2018, http://www.xinhuanet.com/politics/201810/14/c_1123556794.htm?mc_cid=cb8f1f683e\&mc_eid=f25202d7c2 (accessed on 18 October 2018).

19. See e.g.: "陶明伦: 政治坚定业务精通作风过硬” (Tao Minglun: Zhengzhi jianding yewu jingtong zuofeng guoying, Tao Minglun: Political firmness, professional proficiency, and excellent style), CPC News, 30 May 2015, http://cpc.people.com.cn/n/2015/0530/c64102-27080069.html (accessed on 1 January 2019).

20. On these so-called overlapping Party-members (jiaocha dangyuan 交叉党员), see: "父女相隔 38年先后当选主席“双重党籍”引关注” (Funü xiangge 38 nian xianhou dangxuan zhuxi "shuangzhong dangji" yin guanzhu, Daughter elected chairperson 38 years after her father, the "double party" membership attracts attention), Sina, 10 December 2017, http://news.sina.com.cn/ c/nd/2017-12-10/doc-ifypnqvn2646092.shtml (accessed on 7 November 2018). It turns out that in fact members of the other minor political parties do not even have to give up their membership in the other party if they choose to join the CCP.

21. “第十三届全国政协委员名单形成” (Di shisan jie quanguo zhengxie weiyuan mingdan xingcheng, The list of members to the $13^{\text {th }}$ National Committee of the (PPCC), CPPCC Website, http://cppcc.china.com.cn/2018-01/25/content_50299042.htm (accessed on 27 August 2018).

22. Interview with a former member of the national CPPCC, September 2017. Chinese authors, accordingly, occasionally use the neologism "political harmony" (zhengxie 政谐) when characterising the CPPCC and its work "culture." This is a combination of the term 政协 (zhengxie, consultation) and 和谐 (hexie, harmony), resulting in a phonetic equivalent to the Chinese word for "consultation" used in the CPPCC; see e.g. Jiang (2010: 82).

23. Article 30 of the CPPCC Charter. An English translation can be found here: http://www.cppcc. gov.cn/zxww/2018/12/27/ARTI1545876942660350.shtml (accessed on 9 November 2018); emphasis added. 
Table 1 - Selected characteristics of members of the $13^{\text {th }}$ national-level CPPCC (2018)

\begin{tabular}{|l|c|}
\hline Total number of representatives & 2,158 \\
\hline Average age & 55.9 years \\
\hline Number of billionaires & $56(2.6 \%)$ \\
\hline Education-level: university degree & $1971(91 \%)$ \\
\hline Members of an ethnic minority & $244(11.3 \%)$ \\
\hline Number of women & $442(20.5 \%)$ \\
\hline
\end{tabular}

Sources: Authors' own compilation. Membership list from CPPCC website: http://www.cppcc.gov.cn/zxww/2018/01/25/ARTI1516834749863530.shtml, 25 January 2018 (accessed on 28 January 2018); Formation of the $13^{\text {th }}$ CPPCC, Xinhua, http://www.xinhuanet.com/2018-01/25/c_1122310656.htm, 25 January 2018 (accessed on 28 January 2018); "Hurun Rich List 2019", http://www.hurun.net/EN/Article/Details?num=24DD41EE3B19, 26 February 2019 (accessed on 2 March 2019).

underlines that this has been a practice for some time already. Chen Minglu quotes from her interview with one entrepreneurial CPPCC delegate: "Once you sell the enterprise, you will not be a representative any more" (Chen 2016: 326). County-level CPPCC committees also practice this form of differentiated and rather static approach to representation, which means that changing occupation disqualifies delegates from potential renewal of their membership (Yan 2011: 61).

The process of selecting members for the consultative conferences officially rests on recommendation (tuijian 推荐) of candidates to the UFWD, often by one's workplace or one of the mass organisations. After scrutiny by the UFWD, and final approval by the CCP, successful nominees receive an invitation to join the CPPCC. We still know little about the details of this procedure. It turns out, for instance, that the recommendation process is kept secret even from the potential members themselves, and there is no form of "interview" or other personal encounter before the person is formally invited to join the CPPCC. One informant explained that she had not even been in China when she was notified of her invitation to the CPPCC. (24) Upon joining the CPPCC, the selected member's specific representativeness is theoretically to be displayed by assignment to one of the CPPCC's different "circles" (jiebie 界别). ${ }^{(25)}$ These placements are supposed to reflect the person's background, i.e., field of expertise, but are sometimes quite inexplicable. Among our informants, a successful businessperson, for instance, was selected to participate in the Communist Youth League circle, and jokingly described this as a sign that "the CCP must think I look young" - he was 56 years of age. Another private entrepreneur started in the "economics circle" but was later moved to the All-China Women's Federation circle. Members themselves complain about the uneven number of representatives in the different groups and fora, ${ }^{(26)}$ which is understood as undermining the value and purpose of these "circles." At the same time, some informants expressed a rather pragmatic approach to this issue, and reported nonetheless frequently meeting with people "across circle lines." (27) In other words, while the official rhetoric strongly emphasises the importance and necessity of this form of "circle representation," in reality they appear to be somewhat randomly organised.

In sum, looking at both the opaque selection procedures as well as the top-down and seemingly often arbitrary logic of assignment to allegedly functional circles, we would second Thomas Heberer in stating that the CPPCC institutionalises a model of "mobilised representation" (Heberer 2016: 35). While this has been one of the major characteristics of the CPPCC as a political institution all along, it seems that especially after the recent issuance of new rules of conduct, the last spark of "autonomy" and "spontaneity" under its roof has been stifled. It has moreover become increasingly unclear who the CPPCC's "audience" (ibid.: 7) is and what and for whom the conferences are intermediating.

\section{Honour obliges: Delegates' self-perception}

When asked what members themselves believed has made them suitable for the CPPCC and what they thought their ultimate mission as delegates was, our informants usually remained very vague. They claimed not to know anything about the reasons for their selection other than that they were "representative" of some particular functional group. Being asked to speculate, they would note that they perhaps possessed some characteristics that made them more capable of expressing the interests of a specific group than others. Some pointed to particular skills, e.g., in formulating themselves in writing, or collecting historical records - a part of CPPCC delegates' work - as a way to show that were sufficiently useful. Others pointed to their membership in one of the eight minor parties. Due to the institution's goal of ensuring numerical representation, in particular from the other parties, those who join these parties still have relatively easier access to the CPPCC at all levels. As one such member reflected, "I was selected even though there are many others who could probably do a better job." (28)

What was consistent across all localities was the emphasis on the "honorary" aspect of being invited to join the CPPCC system. This may explain some of the rationale behind joining an institution that offers delegates neither wages nor immediate economic benefit. ${ }^{(29)}$ It does, however, further testify to a certain ambiguity that seems to surround the CPPCC in general. For some, the honour of participating in a consultative process reportedly meant an opportunity or even obligation to present their opinions in a forum where some have to listen to what they say. However, many informants had a hard time explaining where the subject-matter was coming from, i.e., how these opinions were generated, and whether and how one could understand intermediation in the CPPCC (i.e. their task of "bridging") procedurally, and not only as a goal or purpose.

The lack of derived representativeness based on (electoral and nonelectoral) constituencies, and the fact that circle and group work in the CPPCC is assigned rather ambiguously and flexibly in a top-down manner, seemed to seriously affect delegates' self-perception. Whereas a somehow ascribed quality or elite-ness was confirmed as the blurry criterion for appointment to the CPPCC, interviewed members - as much as they were quick to retell the official description of the institution also revealed that they, in their actual work, were not necessarily expected to act strictly according to a (rational) group identity and interest.

24. Interviews, Zhejiang Province, September 2017 and April 2018.

25. The CPPCC hosts 34 functional groups. These include the eight other political parties, sectors and associations, and ten so-called "special committees" (zhuanmen weiyuanhui 专门委员会), encompassing important groups and issues such as economy; agriculture and rural issues; Hong Kong, Macao, Taiwan, and overseas Chinese affairs; and foreign relations.

26. “政协委员: 现在文艺界太多委员了, 根本不需要那么多” (Zhengxie weiyuan: xianzai wenyi jie tai duo weiyuan le, genben bu xuyao name duo, CPPCC-member:There are too many members in the literary and artistic circles, there is no need for all of them), Ifeng News, 10 March 2012, http://news.ifeng.com/mainland/special/2012lianghui/detail_2012_03/10/13098132_0.shtml (accessed on 2 January 2019).

27. Interviews, Zhejiang Province, April 2018

28. Interviews with members of local PCCs, Zhejiang Province, April and July 2018

29. Interviews with members of local PCCs, Zhejiang Province, April and July 2018. 
According to CPPCC theory, they are supposed to behave like vanguard, omnipotent individuals with a sense of what the ruling party needs to be consulted on. In reality, informants struggled to explain how exactly that was working.

The officially constructed but apparently futile form of representation and intermediation in the CPPCC system therefore appears to be part of a window-dressing effort, a point that is not lost on delegates themselves. Some take to complaining about the intense and exclusive focus on the CPPCC during the "two sessions" (lianghui 两会, the yearly plenary meetings of the (PPCC and the NPC) at the cost of recognition of their regular off-season work. With constant reporting in the news media, their "honorary" position would be emphasised, while their impact on policy remained underrepresented, one informant stated. (30) But, as one seemingly disillusioned delegate quoted in a Chinese media report was saying: "Once you chose to accept the offer, it is best not to complain [about this system]." (31) What, then, can be said about the CPPCC's regular mode of operation?

\section{Propose or perish? CPPCC members' work}

The "two sessions" are reportedly the most important yearly event for the CPPCC, but media reporting on the meetings is strictly controlled, and articles are written and pre-approved in advance of the meetings. ${ }^{(32)}$ Sometimes, however, related news coverage can make for great entertainment in the otherwise mundane reporting on political affairs in China, especially when celebrities and well-known public intellectuals fall asleep during the meetings or agree to selfies with state media journalists. This "circus," as some describe it, in turn may somewhat influence how CPPCC members are seen and how they view themselves: as representatives for two weeks, but idle when the cameras are off for the rest of the year. ${ }^{(33)} \mathrm{TV}$ reports also mainly focus on how previously drafted policies and governmental budgets are just discussed over again, interspersed with pictures of minority representatives crossing People's Square praising the great work of the CPPCC. ${ }^{(34)}$ Intended to invoke images of unity and harmony for the Chinese and even a global audience, this does not dispel the notion that the CPPCC is a "flower vase" institution with only symbolic meaning for the Chinese political system. Beyond general references to the representatives' diverse backgrounds and their honorary status, the annual session coverage includes very little information about the (potential) results of their meetings and work in general.

But what is supposed to happen all year round, then? According to the CPPCC Charter (updated in 2018, see above), members are required to:

Consult on major national policies before, during, and after implementation;

Put forward comments, criticisms, and suggestions when supervising state organs and their employees;

Carry out studies and surveys on important issues; and Comment and make suggestions, reports, proposals, and recommendations to the CCP and state organs.

This particular emphasis on the consultative function of the CPPCC culminates in the understanding that the main work of CPPCC members is to draft policy proposals ( $t i$ 'an 提案). Compared to proposal drafting work done by the NPC, members of the CPPCC theoretically seem to enjoy more free- dom, as they can raise proposals at any time during the year, both individually and jointly. Writing policy proposals is communicated as a requirement, and failing to do so may cause a person to lose membership in the CPPCC, or at least to miss the opportunity to serve consecutive terms. ${ }^{(35)}$ Proposals usually go through several rounds of deliberation before they are put on paper. Members of the conferences report that raising proposals together would strengthen the quality of these inputs, and by extension, increase the opportunity of making their voices heard, since more people are involved in the process. One might perhaps expect that membership in the functional groups guides the content or theme of their proposals, but in fact, selecting topics to comment on, or issues to raise suggestions about, is left to delegates' own discretion. At the same time, the delegates seem to be aware that their occupational background carries weight in this process, and tend to stay somewhat within the lines of their specific professional knowledge.

Most of these proposals reflect issues that are broadly representative of general public concern, and it is hard to evaluate whether they make a tangible difference. Critics refer to this activity in the CPPCC as a largely one-way process of policy enforcement with the political purpose of maintaining Party hegemony: only proposals oriented toward the official policy line have a chance to succeed (Wang and Groot 2018: 571). In fact, on the basis of the CPPCC's self-conception and the mentioned 2018 Central Committee Opinion on the Conduct of the CPPCC, it can be expected that any "creativity" is only further stifled now. Yet, it is not impossible for proposals to trigger policy reforms, as the mentioned example of the property rights law shows. This case was even more surprising given that CPPCC proposals aimed at structural or legal revisions rarely garner a response. ${ }^{(36)}$ And then again, orthodoxy does not necessarily guarantee success: even Xi Jinping's wife, Peng Liyuan, who served in the CPPCC from 1993 to 2012, has seen her proposals, though perfectly in line with acknowledged "issues of public concern," fall short of implementation (Jeffreys 2016).

Pressure to produce "good proposals" is high. But since most members of the CPPCC have little political experience, they describe being confused about where they are supposed to send their proposals and which governmental departments they can contact to improve their chances of expo-

30. Interview with PRC literary writer on the possible influence of other well-known writers in the CPPCC, August 2018.

31. “张凤阳: 代表和委员谁更应该'放炮'?" (Zhang Fengyang: Daibiao he weiyuan shei geng yinggai "fangpao"?, Zhang Fengyang: People's Congress delegates or CPPCC-members: Who should set off the "biggest blast"?), Ifeng News, 5 March 2014, http://news.ifeng.com/mainland/ special/2014lianghui/riji/detail_2014_03/05/34444769_0.shtml (accessed on 11 August 2018).

32. Interview with a former state media employee, February 2018. China Digital Times obtained information concerning rules about what not to report on covering the 2016 "Two sessions," including: "Do not report on delegates' personal wealth" and "strictly control negative reports in news media"; see: https://chinadigitaltimes.net/2016/03/minitrue-important-notices-coveragetwo-sessions/ (accessed on 15 November 2018).

33. “葛剑雄: 两会期间我是一个'公共产品'" (Ge Jianxiong: Lianghui qijian wo shi yi ge "gonggong chanpin," Ge Jianxiong: I am a "public product" during the two sessions), Ifeng News, 3 March 2014, http://news.ifeng.com/mainland/special/2014lianghui/riji/detail_2014_03/03/3434990 5_0.shtml (accessed on 9 August 2018).

34. Every year, a list of "best news stories on the CPPCC" is published on its official website, featuring articles, videos, and opinion pieces. See e.g. the selection for 2018 here: http://www.rmzxb.com.cn/ $\mathrm{zt} /$ goodnews/index.shtml (accessed on 28 October 2018).

35. Interviews with members of a county-level city PPCC in Zhejiang Province, July 2018.

36. “蒋洪: 涉及制度法律等顶层问题的提案难得到回应” (Jiang Hong: Sheji zhidu falü deng dingceng wenti de ti'an nan dedao huiying, Jiang Hong: Proposals related to top-level issues such as institutional law rarely receive a response), Ifeng News, 7 March 2014, http://news.ifeng.com/ mainland/special/2014lianghui/riji/detail_2014_03/07/34548651_0.shtml (accessed on $10 \mathrm{Au-}$ gust 2018). 
sure. (37) Only some of these proposals are made publicly available, though outspoken representatives have taken to publicising their proposals via social media in advance of plenum debates, reportedly in an effort to stir greater public discussion and gain traction for their suggestions. ${ }^{(38)}$

Another aspect of delegates' work, which is considerably less publicised, yet seems valuable for evaluating the CPPCC's intermediary efforts, is the task of reflecting "social conditions and public opinions" (fanying sheqing minyi 反映社情民意). This is a form of information collection where smaller, more pressing local issues are dealt with in short summaries with suggestions on how to properly handle the situation. Although these opinions are often limited to the conditions in a certain locality, if they are considered important and general enough they can draw attention at higher echelons of the CPPCC system, or be transmitted directly to the relevant ministry or CCP unit, according to interviewees. ${ }^{(39)}$ The process of reflecting these opinions is described as the main "window" (kou $\square$ ) for the public to contribute input to policy-making that concerns them directly. Many local CPPCCS have therefore set up specific websites, email addresses, or direct links on their homepages to promote this kind of intermediation work. The formula is quite simple: one has to point out a problem, come up with a solution, and preferably give some "scientific reference." The proposal committee then discusses the content and sends these reflections to the relevant government department and the Party committee. In contrast to policy proposals, these reflections do not necessarily trigger a response; in fact, they most often do not. ${ }^{(40)}$ However, they are still an important part of representatives' work, and they are used to track the "active" participation of members in the work of the CPPCC.

Our preliminary analysis of a body of a city-level CPPCC committee's "reflections" show that delegates often formulate these opinions as representing "the masses." This is, first of all, not particularly surprising, since it repeats traditional CPPCC discourse and it is the official purpose of these "opinions" to ensure that "the masses are kept satisfied." "(41) Yet, again, this does appear to blur any kind of graspable, particularistic intermediation endeavour for the sake of addressing a vague political collective. However, these documents show that delegates must argue very precisely and document quite thoroughly what the issue is, and that they are expected to provide rather complex suggestions in order to solve the detected problem. Research in a Hebei Province county's CPPCC a few years back revealed that this was considered a task with "enormous political sensitivity and significant purpose" (Yan 2011: 71). In other words, it is possible to imagine that the CPPCCs are carrying out some form of clearer and more effective intermediary function in this area of their work, in particular at the local level. More indepth analysis of these mini-proposals under the current circumstances is needed to reveal, for instance, how they are oriented right now: toward predefined central policy lines, or toward innovative recommendations based on original observations.

\section{Conclusion}

The Chinese Political Consultative Conferences theoretically have a clear mandate: in official portrayals they are supposed to serve a "bridging" function, enabling communication between the government under the leadership of the Communist Party and currents in society, to the widest extent possible (therefore including, in particular, non-CCP forces), for the ultimate sake of policy reform. A brief look at the institutional evolution of the CPPCC system shows that membership composition and principles of what ought to be the subject of alleged intermediation under the roof of the consultative conferences have shifted quite significantly: from a coerced unification of social groups along an exclusively defined Party line, to a greater inclusion of the growing diversity in Chinese society, enabling a more open search for new solutions in times of transition, and then, most recently, back to strict top-down unitary control that leaves less room for innovative consultation.

Our study further revealed that, in reality, CPPCC members, although very aware of the elite status and honour that their mandates imply, usually struggle to make sense of their mission as intermediaries. This may corroborate the general image of the CPPCC: a decorative empty shell institution that, at best, features elites' public show of adherence to the Party and its policies in exchange for personal benefits, which may lend symbolic legitimacy to the regime. However, we would also contend that, at the same time, there may still be small avenues for making innovative proposals while not crossing the red (Party) line, especially for CPPCC members at the local level, and we hold that it is here that more comprehensive and in-depth research is warranted now, if we wish to grasp the potential for political intermediation in China under the current circumstances.

\section{Rebekka Åsnes Sagild is a doctoral research fellow in China Studies at the Department of Culture Studies and Oriental Languages, University of Oslo (r.a.sagild@ikos.uio.no). \\ I Anna Lisa Ahlers is Associate Professor in China Studies at the Department of Culture Studies and Oriental Languages, University of Oslo (a.l.ahlers@ikos.uio.no).}

Manuscript received on 2 November 2018. Accepted on 9 April 2019.

37. “葛剑雄: 俞正声缩短发言时间. 希望多听委员的” (Ge Jianxiong:Yu Zhengsheng suoduan fayan shijian. Xiwang duo ting weiyuan de, Ge Jianxiong:Yu Zhengsheng shortens his speaking time. He wants to listen to committee members), Ifeng News, 4 March 2014, http://news.ifeng.com/mainland/special/2014lianghui/riji/detail_2014_03/04/34417548_0.shtml (accessed on 10 August 2018).

38. E.g., Jiang Hong 蒋洪, a member of the Chinese Kuomintang and professor of finance at Shanghai University of Finance and Economics, who became well-known to the public after refusing to participate in the CPPPC's voting process because of its "un-democratic characteristics." See e.g. his personal diary of the two sessions (两会亲历日记 lianghui qinli riji): http://news.ifeng.com/ mainland/special/2014lianghui/riji/detail_2014_03/08/34570720_0.shtml (accessed on 15 August 2018).

39. Interviews with members of sub-provincial and county-level city PPCCs in Zhejiang Province, April and July 2018.

40. According to the local head of the proposal committee of a county-level city PPCC in Zhejiang Province, interviewed in July 2018.

41. “反映社情民意 - 重在 反应"' (Fanying sheqing minyi - zhong zai "fanying," Reflecting social conditions and public opinions - the focus is on "reaction"), 16 April 2010, N.A. (accessed on 20 August 2018). 


\section{References}

BONNIN, Michel, and Yves CHEVRIER. 1991. "The Intellectual and the State: Social Dynamics of Intellectual Autonomy During the Post-Mao Era." The China Quarterly 127(September): 569-93.

CABESTAN, Jean-Pierre. 2017. "The Party Runs the Show: How the CCP Controls the State and Towers over the Government, Legislature and Judiciary." In Willy Wo-Lap Lam (ed.), Routledge Handbook of the Chinese Communist Party. London and New York: Routledge.

CAO, Cong. 1999. "Red or Expert: Membership in the Chinese Academy of Sciences." Problems of Post-Communism 46(4): 42-55.

CHEN, Minglu. 2016. "China's Private Entrepreneurs and the Party-State: Mutual Dependence and Political Institutionalization." InYingjie Guo (ed.), Handbook on Class and Social Stratification in China. Cheltenham: Edward Elgar Publishing.

CHEN, Minglu. 2015. "From Economic Elites to Political Elites: Private Entrepreneurs in the People's Political Consultative Conference." Journal of Contemporary China 24(94): 613-27.

CHEN, Zhao, Ming LU, and Junzhi HE. 2008. "Power and Political Participation of Entrepreneurs: Evidence from Liuzhou, Guangxi, China." Journal of the Asia Pacific economy 13(3): 298-312.

DICKSON, Bruce J. 2008. Wealth Into Power. Cambridge: Cambridge Unitersity Press.

GROOT, Gerry. 2004. Managing Transitions: The Chinese Communist Party, United Front Work, Corporatism and Hegemony. New York: Routledge.

GROOT, Gerry. 2012. "A Self-Defeating Secret Weapon? The Institutional Limitations of Corporatism on United Front Work." In Jennifer Y.J. Hsu and Reza Hasmath (eds.), The Chinese Corporatist State: Adaptation, Survival and Resistance. London and New York: Routledge.

HEBERER, Thomas. 2016. "Reflections on the Concept of Representation and Its Application to China." Working Papers on East Asian Studies 110: 1-36. https://www.uni-due.de/imperia/md/content/in-east/about/publications_green_series/paper110-2016.pdf (accessed on 24 January 2018).

HOLBIG, Heike. 2006. "Ideological Reform and Political Legitimacy in China: Challenges in the Post-Jiang Era." GIGA Working Paper 18.https://www.giga-hamburg.de/de/system/files/publication s/wp18_holbig.pdf (accessed on 17 september 2018).

JEFFREYS, Elaine. 2016. "Political Celebrities and Elite Politics in Contemporary China." China Information 30(1): 58-80.
JIANG, Zuojun 蒋作君. 2010. 政协学概论 (Zhengxie xue gailun, Introduction to the (PPCC). Anwei: Anwei chubanshe.

LI, Hongbin, Lingsheng MENG, and Junsen ZHANG. 2006. "Why Do Entrepreneurs Enter Politics? Evidence from China." Economic Inquiry 44(3): 559-78.

LIN, Shangli. 2014. "Political Consultative and Consultative Politics in China." In Kenneth G. Lieberthal, Cheng Li, and Yu Keping (eds.), China's Political Development: Chinese and American Perspectives. Washington, DC: Brookings Institution Press.

LU, Peng. 2014. "Wealthy-Gentry Politics: How Are Capitalists in China Chosen for the 'Houses'?" Australian Journal of Political Science 49(2): 157-73.

MANION, Melanie. 2015. Information for Autocrats. Representation in Chinese Local Congresses. Cambridge: Cambridge University Press.

SHUE, Vivienne. 2018. "Party-State, Nation, Empire: Rethinking the Grammar of Chinese Governance." Journal of Chinese Governance 3(3): 268-91.

SUN, Xin, Jiangnan ZHU, and Yiping WU. 2014. "Organizational Clientelism: An Analysis of Private Entrepreneurs in Chinese Local Legislatures." Journal of East Asian Studies 14(1): 1-29.

TRUEX, Rory. 2016. Making Autocracy Work. Representation and Responsiveness in Modern China. Cambridge: Cambridge University Press.

U, Eddy. 2012. "Dangerous Privilege:The United Front and the Rectification Campaign of the Early Mao Years." The China Journal 68: 32-57.

VAN SLYKE, Lyman P. 1967. Enemies and Friends: The United Front in Chinese Communist History. Stanford: Stanford University Press.

WANG, Ray, and Gerry GROOT. 2018. "Who Represents? Xi Jinping's Grand United Front Work, Legitimation, Participation and Consultative Democracy." Journal of Contemporary China 27(112): 1-15.

YAN, Xiaojun. 2011. "Regime Inclusion and the Resilience of Authoritarianism: The Local People's Political Consultative Conference in Post-Mao Chinese Politics." The China Journal 66: 53-75.

YU, Bin. 2015. "Bounded Articulation: An Analysis of CPPCC Proposals, 2008-12." Journal of Chinese Political Science 20(4): 425-49. 